\title{
The Non-Linear Effect of Financial Support on Energy Efficiency: Evidence from China
}

\author{
Shuanglian Chen ${ }^{1}$, Gaoke Liao ${ }^{2, *}$, Benjamin M. Drakeford ${ }^{3}(\mathbb{D})$ and Pierre Failler ${ }^{3}(\mathbb{C}$ \\ 1 Guangzhou International Institute of Finance and Guangzhou University, Guangzhou 510006, China; \\ 15818707232@163.com \\ 2 College of Finance and Statistics, Hunan University, Changsha 410000, China \\ 3 Economics and Finance Subject Group, Portsmouth Business School, University of Portsmouth, \\ Portsmouth PO13DE, UK; ben.drakeford@port.ac.uk (B.M.D.); pierre.failler@port.ac.uk (P.F.) \\ * Correspondence: liaogaoke@hnu.edu.cn
}

Received: 15 February 2019; Accepted: 29 March 2019; Published: 2 April 2019

check for updates

\begin{abstract}
This study examines the non-linear effect of financial support on energy efficiency for 30 provinces in China, over the period 2003 to 2016. Specifically, we find that technological progress is a key factor in improving energy efficiency, regardless of the transition variable or sample chosen. The non-linear effects of the support of different financial sectors on energy efficiency are different. Banks have the greatest positive impact on energy efficiency, but as economic and financial development levels increase, this impact will diminish. The impact of securities on energy efficiency is contrary to bank support, because as the level of economic and financial development increases, the impact of securities on energy efficiency will shift from negative to positive. The impact of insurance support on energy efficiency is not significant.
\end{abstract}

Keywords: financial support; technological progress; energy efficiency; PSTR model

\section{Introduction}

The coupled development of the financial sector and industrial enterprises plays an important role in improving energy efficiency. In China, the emission of energy pollutants is mainly from industrial enterprises, causing economic societal losses and even climate change [1-3]. Increased energy efficiency enables enterprises to achieve greater output with less energy input, thereby reducing pollution emissions and improving air quality [4-6]. The financial sector can reduce the costs of enterprises by providing support to ease the financing constraints of enterprises [7]. Under the background of green development, enterprises have strong incentives to improve their corporate image in order to gain greater advantages in the market [8]. Technological progress is a key element in connecting financial support and energy efficiency.

On the one hand, technological progress is a key element affecting energy efficiency $[9,10]$. Endogenous growth theories attribute the important driving force of economic growth to innovation activities in various fields, supported by the accumulation of knowledge in the whole society [11,12]. Therefore, in addition to science and technology, such as energy conservation and emission reduction, this paper also considers technological progress to include soft technological progress, such as management system innovation and system innovation. Gerarden et al. suggest that energy-efficient technologies offer considerable promise for reducing the financial costs and environmental damages associated with energy use [13]. Costantini et al. show that the introduction and adoption of green technologies are the most cost effective way to reduce environmental pressure, without compromising economic competitiveness [14]. On the other hand, financial support has a fundamentally important impact on technological progress [15-18]. Based on King and Levine's expansion of the new 
Schumpeter growth model, the continuous improvement of the financial system will enable financial intermediaries to obtain more effective project information, so as to better mobilize and use savings, and to invest more funds [19]. In effective projects, this helps firms to diversify risks and promote technological innovation. Amore et al. show that banking development plays a key role in technological progress and that interstate bank deregulation has a significant positive impact on the quantity and quality of innovation activities [20]. Further, Kim and Park suggest that financial development can reduce $\mathrm{CO}_{2}$ emissions by addressing the role of financial markets in renewable energy [21].

However, there is no consistent conclusion on the relationship between financial support and energy efficiency. This is because the heterogeneity of the sample has not been considered. Further, there is currently no literature that directly studies the relationship between financial support and energy efficiency. There are a large number of studies on the role of financial development and carbon emissions, which note that the focus on the role of increased energy efficiency is to reduce carbon emissions. Katircioğlu and Taşpinar point out that both in the long-term and short-term periods of the Turkish economy, financial development had a positive effect on environmental performance and energy management [22]. Saidi and Mbarek find that financial development decreases carbon emissions, implying that financial development minimizes environmental degradation [23]. However, as noted by several authors, the impact of financial development and carbon emissions might be negative. For example, Shahzad et al. found that in Pakistan, increases in financial development would increase carbon emission by $0.165 \%$ [24]. Pata notes that financial development caused increases in $\mathrm{CO}_{2}$ emissions in Turkey [25].

This paper thus considers the non-linear effect of financial support on energy efficiency. Non-linear effects are widespread in the study of financial problems [26-28]. Most of the current studies use linear models, and the results are inconsistent or even contradictory. The environmental Kuznets curve (EKC) depicts an inverted $U$ shape relationship between economic development and environment pollution. A number of studies have illustrated the existence of a positive correlation between financial development and the development of the economy as a whole. Therefore, we hypothesize that there is a nonlinear relationship between financial support and energy efficiency. There are two important channels, which explain the nexus between financial support and energy efficiency. First, financial support enhances energy consumption, which leads to lower energy efficiency. Second, financial support promotes innovation, application, and promotion of technology, which leads to higher energy efficiency. Shahbaz et al. report that the relationship between energy consumption and financial development can be very complex, because numerous impact channels can exist between them [29].

The focus of this paper is to address the nonlinear effect financial support has on energy efficiency in China, which is both the world's largest energy producer and energy consumer, utilizing data from 30 provinces in China. We expand and supplement the existing literature from the following aspects. Firstly, this paper intends to reveal the nonlinear mechanism of financial support on energy efficiency, which can enrich the theoretical research on energy efficiency. Secondly, this paper aims to measure energy efficiency in China using single factor energy efficiency and total factor energy efficiency. Thirdly, the nonlinear effect of financial support on energy efficiency is tested using the panel smooth transition regression (PSTR) model [30]. Finally, this paper addresses the impact of different levels of financial sector support on energy efficiency.

The paper is structured as follows. The next section (Section 2) introduces the PSTR model and the measurement of energy efficiency. Section 3 tests the nonlinear relationship between financial support and energy efficiency and presents the empirical results of China's 30 provincial states level data from 2003 to 2016. Finally, Section 4 concludes the paper and suggests policy recommendations. 


\section{Methodology}

\subsection{Sample and Data Used}

This research is conducted in China and focuses on 30 provinces. As the world's largest energy producer and consumer, China has achieved remarkable economic and financial development with its high-input and high-consumption industrial production model [31,32]. However, this extensive economic development model has resulted in huge energy waste and serious environmental problems [33]. Pollution, resources, and environmental issues have become important factors that have constrained the sustainable development of China's economy. Furthermore, China has experienced very uneven regional development. Using China's regions (provinces) as a research sample, we address the impact of sample heterogeneity on the results and their implications for policy recommendations. The data used in this study are obtained from the Wind database (Wind is mainland China's leading financial database and software services provider. Wind has built up a large, complete, and accurate data warehouse focused on financial securities data, covering stocks, funds, bonds, foreign exchange, insurance, futures, financial derivatives, spot trade, macroeconomics, financial news, and other fields). Due to the different economic systems of Hong Kong, Macao and Taiwan, and mainland China, it is difficult to obtain relevant statistics [34]. Considering the integrity of the data, the sample excludes Hong Kong, Macao, and Taiwan. Annual data are used for 30 Chinese provinces during the period of 2003-2016.

According to the economic development and geographical features of China, there are huge differences in the development of the east, central, and west areas. We divided the sample in to three sub-samples [35,36]: the east area, the central area, and the west area. The east area includes 11 provinces (Beijing, Tianjin, Hebei, Liaoning, Shanghai, Jiangsu, Zhejiang, Fujian, Shandong, Guangdong, and Hainan) with the highest level of economic and financial development in China. The central area includes eight provinces (Shanxi, Jilin, Heilongjiang, Anhui, Jiangxi, Henan, Hubei, and Hunan) where the levels of economic and financial development are lower than the east area but superior to the west area. The west area includes 11 provinces (Inner Mongolia, Chongqing, Sichuan, Guizhou, Guangxi, Yunnan, Shaanxi, Gansu, Ningxia, Qinghai, and Xinjiang) with relatively low levels of economic and financial development.

\subsection{The PSTR Model}

To address the nonlinear effect of financial support on energy efficiency we specify the following PSTR model. The PSTR model can accurately describe the transition between the linear model and the asymmetric model in the process of energy efficiency by selecting different transition variables or transfer functions [30]. The basic expression equation form of the panel smooth transition model is:

$$
\mathrm{y}_{i, t}=\beta_{0} x_{i, t}+\sum_{j=1}^{r} \beta_{j} x_{i, t} g_{j}\left(q_{i, t}^{(j)} ; \gamma_{j} ; c_{j}\right)+\mu_{i}+\varepsilon_{t}
$$

For, $i=1,2, \cdots, N ; t=1,2, \cdots, T . y_{i t}$ is the dependent variable, and $x_{i t}$ is the explanatory variables that changes over time. $\mu_{i}$ indicates the vector of the individual fixed effects and $\varepsilon_{t}$ is a random disturbance. $\beta_{0}$ and $\beta_{j}$ indicate respectively the parameter vector of the linear model and the non-linear model. $g_{j}\left(q_{i, t}^{(j)} ; \gamma_{j} ; c_{j}\right)$ is the function of transition which depends on the transition variable of transition $q_{i, t}^{(j)}$ to the parameter of threshold $c_{j}$ and to the smooth transition parameter $\gamma_{j}$ allows the system to transition gradually. The transition function is set in the form of a logistic function in Equation (2):

$$
g_{j}\left(q_{i, t}^{(j)} ; \gamma_{j} ; c_{j}\right)=\left[1+\exp \left(-\gamma_{j} \prod_{k=1}^{m_{j}}\left(q_{i, t}^{(j)}-c_{j, k}\right)\right)\right]^{-1}
$$


where $\gamma_{j}>0, c_{j, 1} \leq c_{j, 2} \leq \cdots \leq c_{j, m_{j}}$ and $c_{j}$ is a vector of level parameter. $\gamma_{j}$ represents the supposed positive smooth parameter.

\subsection{Energy Efficiency}

Energy efficiency measures can be divided into two categories: single factor energy efficiency and total factor energy efficiency. The single factor energy efficiency indicator, that is, the energy intensity, refers to increasing energy consumption per unit of GDP, which is energy consumption per unit of output value-one of the important indicators reflecting energy efficiency. The energy intensity indicator is simple and easy to understand, easy to use, can be used to conduct country-specific comparative studies, and is widely used in policy as it is relatively easy to calculate and comparable with country characteristics. The total factor energy efficiency considers the interaction and substitution between energy and capital and labor and other production factors, which is more in line with the actual production process than the single factor energy efficiency, and thus is more widely used [37,38]. In order to eliminate the impact of energy efficiency measured by different methods on the results, this paper uses both methods to measure energy efficiency.

Calculating energy efficiency requires calculating energy consumption. According to statistics, the proportion of global coal in energy consumption is around $28 \%$, while the proportion of China's consumption has always remained above $60 \%$, while China's oil, natural gas, hydropower, nuclear energy, and other energy consumption are at a very low level [39]. Since the reform and opening up, China's coal-based energy consumption structure has not changed. This is determined by China's energy distribution pattern of rich coal, lean oil, and low natural gas. Therefore, considering the special circumstances of China, the calculation of energy consumption is based on the consumption of coal, oil, and natural gas.

We can calculate carbon emissions through data on energy consumption. The coal, oil, and natural gas consumption data of all provinces is derived from the Wind database. The energy consumption of coal, oil, and natural gas in each province is converted into a standard coal calculation. The estimated formula for obtaining carbon emissions is:

$$
C E=e \sum_{i=1} \eta_{i} \times \alpha_{i}
$$

In formula (3), CE is carbon dioxide emissions, $e$ is the total energy consumption, $\eta_{i}$ refers to the energy structure, and $\alpha_{i}$ refers to the carbon emission factor for energy consumption. The energy consumption carbon footprint of each energy source are collected from various official websites and shown in Table 1.

Table 1. Carbon emission factors for energy consumption.

\begin{tabular}{|c|c|c|c|}
\hline Data Sources & $\begin{array}{l}\text { Carbon emission Factor } \\
\text { for Coal Consumption } \\
\qquad(t(C) / t)\end{array}$ & $\begin{array}{l}\text { Carbon Emission Factor } \\
\text { for Oil Consumption } \\
(t(C) / t)\end{array}$ & $\begin{array}{c}\text { Carbon Emission Factor } \\
\text { for Natural Gas } \\
\text { Consumption }(t(C) / t)\end{array}$ \\
\hline $\begin{array}{l}\text { Energy Information } \\
\text { Administration-EIA }\end{array}$ & 0.702 & 0.478 & 0.389 \\
\hline $\begin{array}{l}\text { The Institute of Energy } \\
\text { Economics, Japan }\end{array}$ & 0.756 & 0.586 & 0.449 \\
\hline $\begin{array}{l}\text { Chinese Committee } \\
\text { for WCRP }\end{array}$ & 0.726 & 0.583 & 0.409 \\
\hline $\begin{array}{l}\text { Energy Research Institute } \\
\text { National Development and } \\
\text { Reform Commission }\end{array}$ & 0.7476 & 0.5825 & 0.4435 \\
\hline Average & 0.7329 & 0.5574 & 0.4426 \\
\hline
\end{tabular}

Common methods for measuring efficiency are parametric and non-parametric methods. The parametric method needs to construct a specific optimal production preamble function to make 
the efficiency calculation of the decision-making unit. The non-parametric method does not require too many assumptions and directly uses the linear programming method to construct the optimal production frontier. DEA (Data envelopment analysis) is recognized in the literature as a powerful method, more suitable for performance measurement activities than traditional econometric methods such as regression analysis and simple ratio analysis [40,41]. Therefore, the calculation using DEA does not need to set various assumptions in advance, and does not need to look for the specific function form of the production frontier.

The Malmquist index is:

$$
M_{i}^{t}\left(x_{t+1}, y_{t+1}, x_{t}, y_{t}\right)=\left[\frac{D_{i}^{t}\left(x_{t+1}, y_{t+1}\right)}{D_{i}^{t}\left(x_{t}, y_{t}\right)} \times \frac{D_{i}^{t+1}\left(x_{t+1}, y_{t+1}\right)}{D_{i}^{t+1}\left(x_{t}, y_{t}\right)}\right]^{1 / 2}
$$

The index reflects the improvement of total factor productivity for each decision-making unit from period $t$ to $t+1$ under fixed-scale remuneration. If the index is greater than 1 , it indicates that the efficiency has risen, and vice versa.

The Malmquist index can be decomposed into the technical efficiency change index (TEC) and technological progress index (TP):

$$
\begin{gathered}
M_{i}^{t}\left(x_{t+1}, y_{t+1}, x_{t}, y_{t}\right)=\frac{D_{i}^{t+1}\left(x_{t+1}, y_{t+1}\right)}{D_{i}^{t}\left(x_{t}, y_{t}\right)} \times\left[\frac{D_{i}^{t}\left(x_{t+1}, y_{t+1}\right)}{D_{i}^{t+1}\left(x_{t+1}, y_{t+1}\right)} \times \frac{D_{i}^{t}\left(x_{t}, y_{t}\right)}{D_{i}^{t+1}\left(x_{t}, y_{t}\right)}\right]^{1 / 2} \\
=T E C \times T P
\end{gathered}
$$

According to the index construction and decomposition process, as long as the "input-output" indicators are selected, the energy efficiency can be measured and decomposed into TEC and TP. $M_{0}$ indicates the change of energy efficiency of each province from $t$ to $t+1$. $D_{0}^{t}$ and $D_{0}^{t+1}$ represents the distance functions of the $t$ period and the $t+1$ period, respectively. If $M_{0}>1$, this indicates that energy efficiency has improved, and vice versa [42]. In order to show energy efficiency more clearly, this paper uses Equation (6) to calculate the energy efficiency based on 2002, that is, the energy efficiency of all provinces in 2002 was 1.

$$
E E_{i}^{t}=M_{i}^{t} \times E E_{i}^{t-1}
$$

This article analyses China's provinces' total factor energy efficiency from the perspective of factor input and output. Input indicators include energy input, labor input, and capital investment. Output indicators include expected economic output and unanticipated environmental pollution indicators. Among them, the input indicators are the total energy consumption of provinces converted to standard coal, the labor force is the number of employees at the end of the year in each province, and the capital investment is the fixed capital stock of each province. The output indicator is the GDP and carbon dioxide emissions of each province.

Table 2 below summarizes the descriptive statistics for all variables used in this study. For each variable, we present the average value, median, standard deviation, minimum, and maximum values. Descriptive statistics are presented to describe the basic characteristics of data used in this study concerning 30 provinces of China over the period from 2003 to 2016.

The MaxDEA software was used to measure the energy efficiency [43], and the overall results of energy efficiency are shown in Table 3 and Figure 1. From the perspective of the provinces, the energy efficiency in the east is much higher than that in the central and west regions. The average energy efficiency in the east region from 2003 to 2016 was 1.7727, while the energy efficiency in the central and west regions was 1.0502 and 1.0312, respectively. Among all the provinces, Guangdong's energy efficiency improvement is the most obvious, reaching 4.734 in 2016. Heilongjiang's energy efficiency decline is the most obvious, only 0.344 in 2016 . From the overall situation, the energy efficiency in the east has improved gradually since 2013. The overall trend in the central and west regions is relatively 
consistent. From 2003 to 2008, the energy efficiency in the central and western regions has slowly declined. Beginning in 2009, energy efficiency in the central and west regions has slowly increased. By 2016, the energy efficiency in the central and western regions was 1.405 and 1.274, respectively.

Table 2. Descriptive statistics for input-output indexes of energy efficiency.

\begin{tabular}{|c|c|c|c|c|c|c|}
\hline \multirow[b]{2}{*}{ Sample } & & \multicolumn{3}{|c|}{ Input } & \multirow{2}{*}{$\begin{array}{c}\text { Desirable } \\
\text { Output } \\
\text { Gross Domestic } \\
\text { Product in the } \\
\text { Region } \\
\text { (Billion Yuan) }\end{array}$} & \multirow{2}{*}{$\begin{array}{c}\begin{array}{c}\text { Undesirable } \\
\text { Output }\end{array} \\
\text { Carbon } \\
\text { Dioxide } \\
\text { Emissions } \\
\text { (Tons) }\end{array}$} \\
\hline & & $\begin{array}{l}\text { Total Number } \\
\text { of Employees } \\
\text { (Ten Thousand) }\end{array}$ & $\begin{array}{c}\text { Total Energy } \\
\text { consumption } \\
(10,000 \text { Tons of } \\
\text { Standard Coal) }\end{array}$ & $\begin{array}{l}\text { Total Investment in } \\
\text { Fixed Assets of } \\
\text { Industry } \\
\text { (Billion Yuan) }\end{array}$ & & \\
\hline \multirow{4}{*}{ Whole } & Mean & 468.31 & $11,960.99$ & 9245.97 & $14,447.14$ & 7455.07 \\
\hline & Std. Dev. & 316.14 & 7883.32 & 9195.82 & $13,919.62$ & 5234.63 \\
\hline & Min & 42.67 & 683.74 & 255.62 & 390.2 & 390.41 \\
\hline & Max & 1973.28 & $38,899.25$ & $53,322.94$ & $80,854.91$ & $25,050.65$ \\
\hline \multirow{4}{*}{ East } & Mean & 669.09 & $16,163.55$ & $12,535.14$ & $23,023.99$ & 8144.79 \\
\hline & Std. Dev. & 368.51 & 9505.17 & $11,056.87$ & $17,405.11$ & 5564.97 \\
\hline & Min & 191.20 & 3214.97 & 921.30 & 2578.03 & 1397.52 \\
\hline & Max & 1973.28 & $38,899.25$ & $53,322.94$ & $80,854.91$ & $22,522.79$ \\
\hline \multirow{4}{*}{ Central } & Mean & 426.57 & $10,870.06$ & 8862.14 & $11,773.34$ & 8549.60 \\
\hline & Std. Dev. & 110.13 & 4207.13 & 7190.20 & 7196.08 & 3838.82 \\
\hline & Min & 262.02 & 3426.00 & 969.03 & 2662.08 & 3379.71 \\
\hline & Max & 719.32 & $19,863.00$ & $30,011.65$ & $32,665.38$ & $20,263.36$ \\
\hline \multirow{4}{*}{ West } & Mean & 281.67 & 8323.46 & 6032.74 & 7523.11 & 5815.66 \\
\hline & Std. Dev. & 160.71 & 4730.50 & 5856.48 & 6475.57 & 5026.05 \\
\hline & Min & 42.67 & 1122.70 & 255.62 & 390.20 & 431.34 \\
\hline & Max & 846.25 & $20,575.00$ & $28,811.95$ & $32,934.54$ & $25,050.65$ \\
\hline
\end{tabular}

Table 3. Energy efficiency in different regions in China from 2003 to 2016.

\begin{tabular}{|c|c|c|c|c|c|c|c|c|c|c|c|c|c|c|}
\hline & 2003 & 2004 & 2005 & 2006 & 2007 & 2008 & 2009 & 2010 & 2011 & 2012 & 2013 & 2014 & 2015 & 2016 \\
\hline Beijing (E) & .047 & 1.108 & 122 & .149 & .215 & 1.222 & 1.354 & 1.363 & 1.343 & 1.344 & 1.383 & 1.365 & 1.362 & 1.315 \\
\hline Tianjin (E) & 1.077 & 1.046 & 0.987 & 1.018 & 1.078 & 1.272 & 1.624 & 2.059 & 2.191 & 2.229 & 2.569 & 2.744 & 2.964 & 3.059 \\
\hline Liaoning (E) & 0.981 & 1.073 & 1.163 & 1.305 & 1.408 & 1.548 & 1.727 & 1.871 & 1.781 & 2.000 & 2.190 & 2.072 & 1.682 & 1.793 \\
\hline Shanghai (E) & 0.986 & 1.024 & 1.041 & 1.047 & 1.086 & 1.117 & 1.150 & 1.099 & 1.172 & 1.240 & 1.282 & 1.248 & 1.155 & 1.027 \\
\hline Jiangsu (E) & 1.294 & 1.295 & 1.278 & 1.394 & 1.536 & 1.786 & 2.136 & 2.574 & 2.999 & 3.349 & 3.952 & 4.265 & 4.465 & 4.492 \\
\hline Shandong (E) & 1.277 & 1.337 & 1.485 & 1.580 & 1.645 & 1.882 & 2.225 & 2.490 & 2.621 & 2.834 & 3.114 & 3.245 & 3.420 & 3.496 \\
\hline Guangdong (E) & 1.077 & 1.125 & 1.137 & 1.163 & 1.252 & 1.418 & 1.730 & 2.363 & 3.724 & 3.828 & 5.018 & 5.078 & 4.931 & 4.734 \\
\hline Hainan (E) & 0.946 & 0.871 & 0.806 & 0.734 & 0.661 & 0.610 & 0.629 & 0.597 & 0.560 & 0.599 & 0.668 & 0.725 & 0.765 & 0.755 \\
\hline Shanxi (C) & 0.826 & 0.686 & 0.605 & 0.573 & 0.522 & 0.462 & 0.521 & 0.455 & 0.396 & 0.407 & 0.423 & 0.420 & 0.421 & 0.403 \\
\hline Jilin (C) & 0.878 & 0.788 & 0.803 & 0.871 & 0.926 & 0.991 & 1.107 & 1.137 & 0.922 & 1.019 & 1.046 & 1.079 & 1.157 & 1.200 \\
\hline Heilongjiang (C) & 0.897 & 0.781 & 0.683 & 0.630 & 0.583 & 0.504 & 0.499 & 0.441 & 0.385 & 0.390 & 0.405 & 0.366 & 0.353 & 0.344 \\
\hline Hubei (C) & 0.931 & 0.865 & 0.797 & 0.771 & 0.659 & 0.627 & 0.660 & 0.679 & 0.695 & 0.739 & 0.816 & 0.832 & 0.854 & 0.862 \\
\hline Hunan (C) & 0.945 & 0.891 & 0.894 & 0.863 & 0.829 & 0.816 & 0.902 & 0.924 & 0.922 & 0.971 & 1.103 & 1.178 & 1.316 & 1.446 \\
\hline Inner Mongolia (W) & 0.970 & 1.054 & 1.159 & 1.196 & 1.214 & 1.131 & 1.302 & 1.319 & 1.249 & 1.299 & 1.490 & 1.758 & 1.356 & 1.465 \\
\hline Guangxi (W) & 0.932 & 0.835 & 0.826 & 0.804 & 0.817 & 0.849 & 1.083 & 1.339 & 1.673 & 2.021 & 2.257 & 2.338 & 2.437 & 2.900 \\
\hline Chongqing $(\mathrm{W})$ & 1.098 & 1.159 & 1.214 & 1.316 & 1.446 & 1.562 & 1.906 & 2.148 & 2.272 & 2.333 & 2.546 & 2.597 & 2.563 & 2.463 \\
\hline Sichuan (W) & 1.010 & 0.965 & 1.007 & 0.993 & 1.023 & 1.079 & 1.502 & 1.598 & 1.461 & 1.554 & 1.807 & 1.735 & 1.615 & 1.551 \\
\hline Guizhou (W) & 0.935 & 0.849 & 0.776 & 0.708 & 0.630 & 0.532 & 0.529 & 0.479 & 0.433 & 0.424 & 0.413 & 0.405 & 0.416 & 0.451 \\
\hline Yunnan (W) & 0.973 & 0.904 & 1.001 & 1.019 & 1.034 & 0.982 & 1.055 & 1.014 & 0.956 & 0.971 & 1.004 & 0.948 & 0.905 & 0.915 \\
\hline Shaanxi (W) & 0.940 & 0.847 & 0.772 & 0.732 & 0.712 & 0.667 & 0.690 & 0.652 & 0.615 & 0.654 & 0.753 & 0.792 & 0.816 & 0.858 \\
\hline Gansu (W) & 0.915 & 0.794 & 0.730 & 0.660 & 0.598 & 0.533 & 0.539 & 0.493 & 0.459 & 0.481 & 0.536 & 0.555 & 0.580 & 0.581 \\
\hline Qinghai (W) & 0.981 & 0.934 & 0.921 & 0.937 & 0.888 & 0.789 & 0.902 & 0.849 & 0.896 & 1.018 & 1.181 & 1.217 & 1.247 & 1.402 \\
\hline Ningxia (W) & 0.944 & 0.868 & 0.848 & 0.786 & 0.716 & 0.674 & 0.707 & 0.697 & 0.630 & 0.705 & 0.797 & 0.887 & 0.942 & 0.910 \\
\hline
\end{tabular}




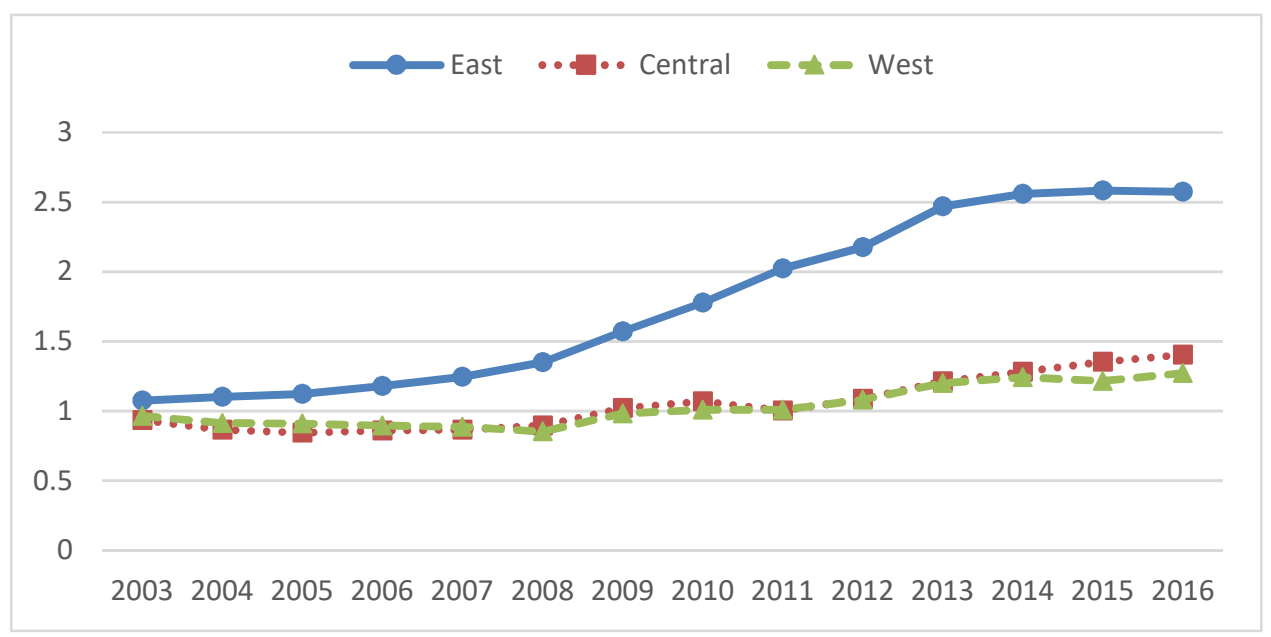

Figure 1. China's regional average energy efficiency.

\subsection{Variables Definition}

Financial support is mainly considered from the perspectives of banking, securities, and insurance. Financial support is measured by the ratio of total bank loans to GDP, the ratio of total market capitalization of listed companies to GDP, and the depth of insurance. In order to correctly identify the impact of financial support and technological progress on the energy efficiency, this paper improves the accuracy of empirical results by setting control variables. Government intervention capacity (GOV) is an effective remedy to compensate for market failures, and plays an important role in the loss of efficiency in the energy industry. This indicator is calculated by the annual fiscal expenditure of the provinces in China as a percentage of the province's GDP. The large inflow of foreign direct investment (FDI) capital not only brings sufficient capital for economic development, but also provides research and development funds for energy technology improvement. This indicator is calculated by the proportion of the actual use of foreign capital in the provinces of China to the province's GDP. The energy consumption structure (ESC) has a major impact on energy efficiency. In areas such as coal, petrochemical, and other consumer structures, the emission of carbon and other pollutants is higher, which is not conducive to regional environmental quality improvement and increased energy efficiency. This indicator is calculated by the proportion of coal consumption in each province in China accounting for the total energy consumption of the province. The energy consumption intensity of different industries is quite different. The more the energy-consuming industry in a certain region accounts for a greater proportion of the national economy of the whole region, the more difficult it is to improve energy efficiency. This indicator is calculated by the ratio of the tertiary industry output value in each province of China to the province's GDP. The descriptive statistic of the data are given in Table 4 .

The heterogeneity between regions is mainly reflected in the difference in economic and financial development levels. Therefore, this paper selects the level of economic development (EDL) and the level of financial development (FIN) as transfer variables to study the non-linear effects of financial support on energy efficiency. The level of economic development is measured by GDP per capita, and the level of financial development is measured by the sum of bank, securities, and insurance support.

To investigate the impact of financial support on energy efficiency, we will specify the following two models. In this model, EDL is the first transition variable, and FIN is the second transition variable. Hence, the two empirical model can be written as follows:

$$
\begin{gathered}
\mathrm{EE}_{i, t}=\mu_{i}+\alpha_{0} \mathrm{TP}_{i, t}+\alpha_{1} \operatorname{LOAN}_{i, t}+\alpha_{2} \text { STOCK }_{i, t}+\alpha_{3} \operatorname{INSURE}_{i, t}+\alpha_{4} X_{i, t}+ \\
\sum_{j=1}^{r}\left(\beta_{0} T E C H_{i, t}+\beta_{1} \operatorname{LOAN}_{i, t}+\beta_{2} \operatorname{STOCK}_{i, t}+\beta_{3} \operatorname{INSURE}_{i, t}\right) g_{j}\left(\operatorname{EDL}_{i, t}^{(j)} ; \gamma_{j} ; c_{j}\right)+\varepsilon_{t}
\end{gathered}
$$




$$
\begin{gathered}
\mathrm{EE}_{i, t}=\mu_{i}+\alpha_{0} \text {TP}_{i, t}+\alpha_{1} \text { LOAN }_{i, t}+\alpha_{2} \text { STOCK }_{i, t}+\alpha_{3} \operatorname{INSURE}_{i, t}+\alpha_{4} X_{i, t}+ \\
\sum_{j=1}^{r}\left(\beta_{0} \operatorname{TECH}_{i, t}+\beta_{1} \operatorname{LOAN}_{i, t}+\beta_{2} \text { STOCK }_{i, t}+\beta_{3} \operatorname{INSURE}_{i, t}\right) g_{j}\left(\text { FIN }_{i, t}^{(j)} ; \gamma_{j} ; c_{j}\right)+\varepsilon_{t}
\end{gathered}
$$

In the nonlinear model described above, $i=1, \ldots, N$ and $t=1, \ldots, T$ where $N$ and $T$ denote the cross-section and time dimensions of the panel, respectively, $\mathrm{EE}_{i, t}$ is the energy efficiency, $X_{i, t}$ is a vector of control variables, $\mu_{i}$ is included in the model specification to reflect fixed individual-effects, and $\varepsilon_{t}$ is the error term.

Table 4. Descriptive statistic of the data.

\begin{tabular}{cccccc}
\hline Variables & Descriptive & Mean & Std. Dev & Min & Max \\
\hline EE & Energy efficiency & 1.3085 & 0.0973 & 0.3435 & 5.0785 \\
TP & Technical progress & 1.0356 & 0.0962 & 0.6730 & 1.3410 \\
LOAN & Total loans/GDP & 1.1517 & 0.3992 & 0.5372 & 2.5847 \\
STOCK & Total market capitalization/GDP & 0.5875 & 1.4016 & 0.0578 & 18.6363 \\
INSURE & Insurance penetration & 2.7021 & 1.0134 & 0.4467 & 7.3900 \\
GOV & Local government expenditure on science & 0.2043 & 0.0921 & 0.0792 & 0.6274 \\
FDI & and technology & 0.3637 & 0.2823 & 0.0058 & 1.2999 \\
ESC & Foreign direct investment & 0.6847 & 0.2618 & 0.0870 & 1.4495 \\
IS & Coal consumption/energy consumption & 0.4160 & 0.0861 & 0.2860 & 0.8023 \\
EDL & Share of service sector/GDP & 3.3431 & 2.2906 & 0.3701 & 11.8198 \\
FIN & GDP per capita & 4.4412 & 2.3808 & 1.4358 & 26.1564 \\
\hline
\end{tabular}

\section{Empirical Analysis}

\subsection{Results of Pre-Tests}

Before testing the PSTR model, some pre-tests were undertaken. The first one tested for stationarity of all variables used. The second tested the linearity or homogeneity and the third test was done to identify the number of transition functions. Table 5 presents the results of the panel unit root test. Table 6 below summarizes the results of the test of linearity based on the statistics of Lagrange multiplier Wald test (LM), Fisher test (LMF), and the likelihood ratio test (LRT).

The procedures of PSTR specification rely on the assumption that all variables in the model are I(0) process. To test for stationarity, we used the Levin-Lin-Chu (LLC) test and the Fisher-augmented Dickey-Fuller (Fisher-ADF) test [44,45]. Results displayed in Table 5 indicate that the LLC and Fisher-ADF tests rejected the null hypothesis (non-stationarity) at both the $1 \%$ and $5 \%$ significance level for all variables used in this study. The results in Table 5 show that our data are stationary and suitable for the next step of analysis. From these results, we can conclude that all data are $\mathrm{I}(0)$ process.

Table 5. Panel unit root test.

\begin{tabular}{ccc}
\hline Variables & LLC & Fisher-ADF \\
\hline EE & $-3.6816(0.000)$ & $155.95(0.000)$ \\
TP & $-3.8328(0.000)$ & $155.73(0.000)$ \\
LOAN & $-7.0140(0.000)$ & $144.40(0.000)$ \\
STOCK & $-13.6992(0.000)$ & $197.67(0.000)$ \\
INSURE & $-4.3744(0.000)$ & $128.53(0.000)$ \\
GOV & $-5.893(0.000)$ & $106.10(0.000)$ \\
FDI & $-5.0639(0.000)$ & $128.06(0.000)$ \\
ESC & $-9.5078(0.000)$ & $153.92(0.000)$ \\
IS & $-3.4194(0.000)$ & $68.64(0.208)$ \\
EDL & $-5.6636(0.000)$ & $100.85(0.001)$ \\
FIN & $-4.3613(0.000)$ & $112.99(0.000)$ \\
\hline
\end{tabular}

Note: p-statistics are shown in parentheses. 
Table 6. Linearity test.

\begin{tabular}{|c|c|c|c|c|c|c|c|}
\hline \multirow{2}{*}{ Transition Variable } & \multirow{2}{*}{ Sample } & \multicolumn{3}{|c|}{$H_{0}: r=0 ; H_{1}: r=1$} & \multicolumn{3}{|c|}{$H_{0}: r=1 ; H_{1}: r=2$} \\
\hline & & LM & $\mathbf{L M}_{\mathrm{F}}$ & LRT & LM & $\mathbf{L M}_{\mathbf{F}}$ & LRT \\
\hline \multirow{8}{*}{ EDL } & \multirow{2}{*}{ Whole } & 82.619 & 11.827 & 92.843 & 11.261 & 1.219 & 11.426 \\
\hline & & $(0.000)$ & $(0.000)$ & $(0.000)$ & $(0.187)$ & $(0.287)$ & $(0.179)$ \\
\hline & \multirow{2}{*}{ East } & 30.145 & 4.107 & 33.548 & 11.580 & 1.128 & 12.038 \\
\hline & & $(0.000)$ & $(0.000)$ & $(0.000)$ & $(0.171)$ & $(0.350)$ & $(0.150)$ \\
\hline & \multirow{2}{*}{ Central } & 28.605 & 4.116 & 33.030 & 5.410 & 1.233 & 5.445 \\
\hline & & $(0.000)$ & $(0.000)$ & $(0.000)$ & $(0.248)$ & $(0.296)$ & $(0.245)$ \\
\hline & \multirow{2}{*}{ West } & 103.182 & 34.263 & 170.739 & 11.305 & 1.021 & 11.741 \\
\hline & & $(0.000)$ & $(0.000)$ & $(0.000)$ & $(0.255)$ & $(0.427)$ & $(0.228)$ \\
\hline \multirow{8}{*}{ FIN } & \multirow{2}{*}{ Whole } & 117.072 & 18.454 & 137.238 & 17.614 & 2.003 & 17.994 \\
\hline & & $(0.000)$ & $(0.000)$ & $(0.000)$ & $(0.244)$ & $(0.456)$ & $(0.214)$ \\
\hline & \multirow{2}{*}{ East } & 43.632 & 6.671 & 51.302 & 10.738 & 1.115 & 11.130 \\
\hline & & $(0.000)$ & $(0.000)$ & $(0.000)$ & $(0.217)$ & $(0.358)$ & $(0.194)$ \\
\hline & \multirow{2}{*}{ Central } & 16.279 & 2.041 & 17.591 & 15.953 & 1.661 & 17.210 \\
\hline & & $(0.039)$ & $(0.049)$ & $(0.025)$ & (0.043) & $(0.121)$ & $(0.121)$ \\
\hline & \multirow{2}{*}{ West } & 44.804 & 6.924 & 52.947 & 11.243 & 1.051 & 10.842 \\
\hline & & $(0.000)$ & $(0.000)$ & $(0.000)$ & $(0.211)$ & (0.403) & (0.188) \\
\hline
\end{tabular}

Note: p-statistics are shown in parentheses.

The objective of this empirical study was to confirm that there is a non-linear relationship. To this end, we conducted a test of linearity against the PSTR model [30]. The null hypothesis was H0: $\beta_{1}=0$ and the alternative was H1: $\beta_{1} \neq 0$. However, the test was nonstandard since, under H0, the PSTR model contained unidentified nuisance parameters. The transition function was replaced by its first order Taylor expansion round $\gamma=0$. The null hypothesis of this test became H0: $\gamma=0$. This null hypothesis could be conveniently tested by the Wald and likelihood ratio tests. The test can be written in the Equation (9) as:

$$
L M=\frac{T N\left(S S R_{0}-S S R_{1}\right)}{S S R_{0}}, L M_{F}=\frac{\left(S S R_{0}-S S R_{1}\right) / m k}{S S R_{1} /(T N-N-m k)}, L R T=-2 \log \frac{S S R_{1}}{S S R_{0}}
$$

where $S S R_{0}$ is the panel sum of squared residuals under $H 0$ and $S S R_{1}$ is the panel sum of squared residuals under H1. LMF is assumed to follow Fisher distribution with $m k$ and $T N-N-m k$ degrees of freedom $(F(m k, T N-N-m k))$. Under the null hypothesis, all linearity tests follow a chi-2 distribution with $k$ degrees of freedom $\left(\chi^{2}(k)\right)$.

If the non-linearity test rejects the original hypothesis, further surplus non-linearity tests (H0: $\mathrm{r}=1 ; \mathrm{H1}: \mathrm{r}=2$ ) are required, which means the test has one or two transition functions. At this point, the smoothing parameter for the second transition function is expanded into a first-order Taylor linear expression at 0 , and an auxiliary regression equation is constructed. Using a method similar to a linearity test, the LM, LMF, and LRT statistics are calculated. If $\mathrm{H} 0$ is still rejected, then the remaining non-linearity test is continued until $\mathrm{H} 0$ cannot be rejected. Finally, the number of optimal transition functions $r$ for the model can be obtained.

The model's non-linearity test and residual nonlinear test results are shown in Table 6.

The Table 6 results show that there are non-linear effects of financial support on energy efficiency, and one transfer function. We can see the three statistics of the nonlinear test LM, LMF, and LRT are significant at the $1 \%$ level, thus strongly rejecting the number of transition functions as being equal to the null hypothesis of 0 , that is, the number of transfer functions should be at least 1 , there is a nonlinear transition mechanism, and the PSTR model should be used for estimation. In the remaining non-linear tests, the LM, LMF, and LRT statistics in all models are not significant, which means the number of transfer functions should be considered to be 1 . Therefore, the number of the transfer functions $r$ are all determined to be 1 . 


\subsection{PSTR Estimates of Economic Development}

To further examine the impact of financial support and technological progress on energy efficiency, this paper uses the interactions of technological progress and financial support as explanatory variables to verify the non-linear effects of financial support on energy efficiency through technological progress. Figure 2 presents the smooth transfer function when EDL and FIN are transfer variables. Tables 7 and 8 present the estimation of the PSTR model for the whole sample of 30 provinces of China and the three sub-samples of the east, central, and west regions during the period of 2003-2016, with economic development level as the transition variable. Tables 9 and 10 present the estimation of the PSTR model for the whole sample of 30 provinces of China and the three sub-samples of the east, central, and west regions during the period of 2003-2016, with financial development level as the transition variable.

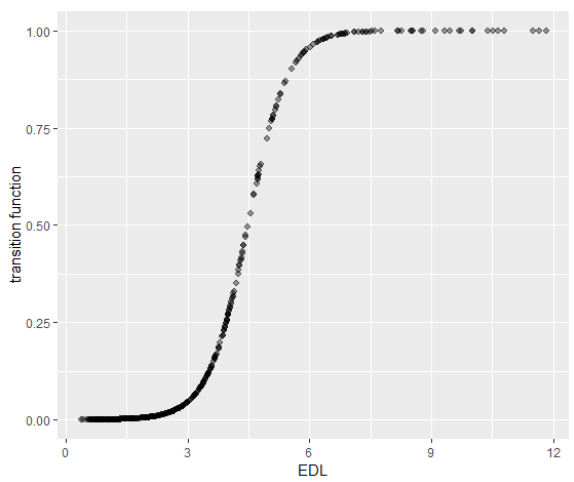

(a) EDL as transition variable

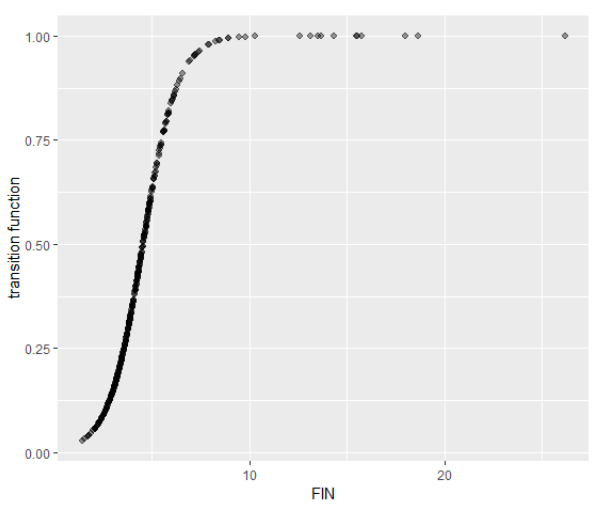

(b) FIN as transition variable

Figure 2. Estimated transition function of the panel smooth transition model.

Table 7. Coefficient estimation of the panel smooth transition regression (PSTR) model: economic development (EDL).

\begin{tabular}{|c|c|c|c|c|c|c|c|c|}
\hline \multirow[t]{2}{*}{ Variable } & \multicolumn{2}{|c|}{ Whole } & \multicolumn{2}{|c|}{ East } & \multicolumn{2}{|c|}{ Central } & \multicolumn{2}{|c|}{ West } \\
\hline & Linear & Nonlinear & Linear & Nonlinear & Linear & Nonlinear & Linear & Nonlinear \\
\hline $\mathrm{TP}$ & $\begin{array}{c}0.6526^{* * *} \\
(9.3042)\end{array}$ & $\begin{array}{c}0.1206^{* *} \\
(2.187)\end{array}$ & $\begin{array}{c}0.4478^{* * *} \\
(7.1)\end{array}$ & $\begin{array}{c}0.3906^{* * *} \\
(2.6215)\end{array}$ & $\begin{array}{c}0.7021^{* * *} \\
(7.0485)\end{array}$ & $\begin{array}{l}0.3373 * * \\
(2.3422)\end{array}$ & $\begin{array}{l}0.3716^{* *} \\
(2.5383)\end{array}$ & $\begin{array}{l}0.4768^{* *} \\
(2.3581)\end{array}$ \\
\hline LOAN & $\begin{array}{l}0.4956^{* *} \\
(2.5157)\end{array}$ & $\begin{array}{l}-0.2354 \\
(-1.6724)\end{array}$ & $\begin{array}{l}1.056^{* * *} \\
(2.9797)\end{array}$ & $\begin{array}{l}-1.004^{* *} \\
(-2.1066)\end{array}$ & $\begin{array}{c}0.23 * \\
(1.6674)\end{array}$ & $\begin{array}{l}1.213^{* *} \\
(2.5537)\end{array}$ & $\begin{array}{c}0.3462 * * * \\
(3.7704)\end{array}$ & $\begin{array}{c}0.5185^{* * *} \\
(3.0198)\end{array}$ \\
\hline STOCK & $\begin{array}{c}-0.019^{*} \\
(-1.7546)\end{array}$ & $\begin{array}{c}0.0132 \\
(0.3286)\end{array}$ & $\begin{array}{c}0.2153^{* * *} \\
(2.8722)\end{array}$ & $\begin{array}{c}-0.2385^{* * *} \\
(-3.3157)\end{array}$ & $\begin{array}{l}0.0603^{*} \\
(1.6917)\end{array}$ & $\begin{array}{c}0.1152 \\
(0.2934)\end{array}$ & $\begin{array}{c}-0.0157 \\
(-0.3667)\end{array}$ & $\begin{array}{c}0.7325^{* * *} \\
(3.1051)\end{array}$ \\
\hline INSURE & $\begin{array}{c}0.0039 \\
(0.1222)\end{array}$ & $\begin{array}{c}-0.0293 \\
(-0.5393)\end{array}$ & $\begin{array}{c}0.0869 \\
(1.6029)\end{array}$ & $\begin{array}{l}-0.0961 * \\
(-1.8055)\end{array}$ & $\begin{array}{c}-0.0972 * * * \\
(-3.4406)\end{array}$ & $\begin{array}{c}0.0937 \\
(1.2115)\end{array}$ & $\begin{array}{c}0.0316 \\
(0.7412)\end{array}$ & $\begin{array}{c}-0.1549 \text { ** } \\
(-2.415)\end{array}$ \\
\hline GOV & $\begin{array}{l}-0.5069 * * \\
(-2.4283)\end{array}$ & $\begin{array}{c}1.002 \\
(0.9882)\end{array}$ & $\begin{array}{c}2.216^{*} \\
(1.8956)\end{array}$ & $\begin{array}{c}-1.546 \\
(-0.9923)\end{array}$ & $\begin{array}{l}2.591 * * * \\
(3.2943)\end{array}$ & $\begin{array}{c}-3.34 * \\
(-1.7387)\end{array}$ & $\begin{array}{l}-1.176^{* * *} \\
(-3.2158)\end{array}$ & $\begin{array}{c}0.0974 \\
(0.1662)\end{array}$ \\
\hline FDI & $\begin{array}{c}0.0034 \\
(0.0322)\end{array}$ & $\begin{array}{l}-0.2101 \\
(-1.129)\end{array}$ & $\begin{array}{c}-0.0488 \\
(-0.2797)\end{array}$ & $\begin{array}{c}-0.0066 \\
(-0.0298)\end{array}$ & $\begin{array}{c}-0.1248 \\
(-0.5799)\end{array}$ & $\begin{array}{c}0.5978 \\
(1.0486)\end{array}$ & $\begin{array}{c}0.2128 \\
(1.1206)\end{array}$ & $\begin{array}{l}-0.1388 \\
(-0.3777)\end{array}$ \\
\hline ESC & $\begin{array}{c}0.342 \\
(0.9735)\end{array}$ & $\begin{array}{l}-0.6467 \\
(-1.3532)\end{array}$ & $\begin{array}{c}1.63 * * \\
(1.9893)\end{array}$ & $\begin{array}{l}-2.902 * * * \\
(-3.4049)\end{array}$ & $\begin{array}{c}0.1439 \\
(0.5599)\end{array}$ & $\begin{array}{l}-0.3267 \\
(-1.0335)\end{array}$ & $\begin{array}{c}0.2238 \\
(1.3401)\end{array}$ & $\begin{array}{l}0.2519 * \\
(1.8387)\end{array}$ \\
\hline IS & $\begin{array}{c}-0.0223 \text { ** } \\
(-2.085)\end{array}$ & $\begin{array}{c}0.0167 \\
(0.8497)\end{array}$ & $\begin{array}{c}-0.0985 * * * \\
(-3.9903)\end{array}$ & $\begin{array}{l}0.072 * * * \\
(2.8876)\end{array}$ & $\begin{array}{c}0.0001 \\
(0.0138)\end{array}$ & $\begin{array}{l}-0.0346^{* *} \\
(-2.3093)\end{array}$ & $\begin{array}{l}-0.0061 \\
(-0.7404)\end{array}$ & $\begin{array}{c}-0.0278^{*} \\
(-1.9536)\end{array}$ \\
\hline c & \multicolumn{2}{|c|}{4.495} & \multicolumn{2}{|c|}{4.394} & \multicolumn{2}{|c|}{4.31} & \multicolumn{2}{|c|}{2.966} \\
\hline$\gamma$ & \multicolumn{2}{|c|}{2.533} & \multicolumn{2}{|c|}{3.0460} & \multicolumn{2}{|c|}{1.533} & \multicolumn{2}{|c|}{3.004} \\
\hline $\begin{array}{l}\text { Number of } \\
\text { observations }\end{array}$ & \multicolumn{2}{|c|}{420} & \multicolumn{2}{|c|}{154} & \multicolumn{2}{|c|}{112} & \multicolumn{2}{|c|}{154} \\
\hline
\end{tabular}

Note: t-statistics are shown in parentheses below the estimated coefficients. ${ }^{*}, * *$, and ${ }^{* * *}$ denote statistical significance at the $10 \%, 5 \%$, and $1 \%$ levels, respectively.

Under different regimes of economic development and financial development, financial support has a non-linear impact on energy efficiency. Whether EDL or FIN is used as a transition variable, most of the non-linear effects of financial support on energy efficiency have passed the significance 
test. Taking the east, central, and west regions as a sub-sample, the results are still valid. It can be seen that the non-linear effects of financial support on energy efficiency are widespread.

Table 8. Interaction coefficient estimation of the PSTR model: EDL.

\begin{tabular}{|c|c|c|c|c|c|c|c|c|}
\hline \multirow[t]{2}{*}{ Variable } & \multicolumn{2}{|c|}{ Whole } & \multicolumn{2}{|c|}{ East } & \multicolumn{2}{|c|}{ Central } & \multicolumn{2}{|c|}{ West } \\
\hline & Linear & Nonlinear & Linear & Nonlinear & Linear & Nonlinear & Linear & Nonlinear \\
\hline $\mathrm{TP} \times \mathrm{LOAN}$ & $\begin{array}{l}0.5787^{* * *} \\
(12.7383)\end{array}$ & $\begin{array}{c}-0.1489 \text { ** } \\
(-2.117)\end{array}$ & $\begin{array}{c}0.5304^{* * *} \\
(4.1405)\end{array}$ & $\begin{array}{l}-0.086^{*} \\
(-1.7156)\end{array}$ & $\begin{array}{l}0.7167 * * * \\
(9.9404)\end{array}$ & $\begin{array}{c}-0.0351 \\
(-0.1185)\end{array}$ & $\begin{array}{l}0.42 * * * \\
(6.422)\end{array}$ & $\begin{array}{l}0.2846^{* * *} \\
(3.3267)\end{array}$ \\
\hline $\mathrm{TP} \times \mathrm{STOCK}$ & $\begin{array}{l}-0.0624^{*} \\
(-1.9388)\end{array}$ & $\begin{array}{l}0.0671^{*} \\
(1.8495)\end{array}$ & $\begin{array}{l}-0.1199 * * \\
(-1.9611)\end{array}$ & $\begin{array}{l}0.1205^{*} \\
(1.7579)\end{array}$ & $\begin{array}{l}-0.0258 \\
(-0.61)\end{array}$ & $\begin{array}{c}-0.2638 \text { ** } \\
(-2.297)\end{array}$ & $\begin{array}{c}0.0024 \\
(1.0802)\end{array}$ & $\begin{array}{c}-0.2281 \\
(-1.0565)\end{array}$ \\
\hline $\mathrm{TP} \times \mathrm{INSURE}$ & $\begin{array}{c}0.0076 \\
(0.1766)\end{array}$ & $\begin{array}{l}0.0735 \\
(0.718)\end{array}$ & $\begin{array}{l}0.0095 \\
(0.4418)\end{array}$ & $\begin{array}{c}0.077 \\
(1.5599)\end{array}$ & $\begin{array}{c}0.0058 \\
(0.2431)\end{array}$ & $\begin{array}{c}-0.0306 \\
(-0.3852)\end{array}$ & $\begin{array}{c}0.0248 \\
(1.1058)\end{array}$ & $\begin{array}{c}-0.0747 * * * \\
(-3.619)\end{array}$ \\
\hline FDI & $\begin{array}{l}-0.1761 \\
(-0.9442)\end{array}$ & - & $\begin{array}{c}-0.237 \\
(-1.6177)\end{array}$ & - & $\begin{array}{c}0.1178 \\
(0.5036)\end{array}$ & - & $\begin{array}{c}-0.1824 \\
(-1.2071)\end{array}$ & - \\
\hline ESC & $\begin{array}{c}0.2299 \\
(1.0963)\end{array}$ & - & $\begin{array}{l}1.001 \text { * } \\
(1.817)\end{array}$ & - & $\begin{array}{c}-0.0811 \\
(-0.3704)\end{array}$ & - & $\begin{array}{c}0.1011 \\
(0.6822)\end{array}$ & - \\
\hline IS & $\begin{array}{c}-0.0201^{* * *} \\
(-3.0403)\end{array}$ & - & $\begin{array}{l}-0.0592 * * \\
(-2.5057)\end{array}$ & - & $\begin{array}{c}-0.0111^{* * *} \\
(-4.0862)\end{array}$ & - & $\begin{array}{l}-0.0079 \\
(-1.4921)\end{array}$ & - \\
\hline $\begin{array}{l}\text { Number of } \\
\text { observations }\end{array}$ & \multicolumn{2}{|c|}{420} & \multicolumn{2}{|c|}{154} & \multicolumn{2}{|c|}{112} & \multicolumn{2}{|c|}{154} \\
\hline
\end{tabular}

Note: t-statistics are shown in parentheses below the estimated coefficients. ${ }^{*},{ }^{* *}$, and ${ }^{* * *}$ denote statistical significance at the $10 \%, 5 \%$, and $1 \%$ levels, respectively.

Table 9. Coefficient estimation of the PSTR model: financial development (FIN).

\begin{tabular}{|c|c|c|c|c|c|c|c|c|}
\hline \multirow[t]{2}{*}{ Variable } & \multicolumn{2}{|c|}{ Whole } & \multicolumn{2}{|c|}{ East } & \multicolumn{2}{|c|}{ Central } & \multicolumn{2}{|c|}{ West } \\
\hline & Linear & Nonlinear & Linear & Nonlinear & Linear & Nonlinear & Linear & Nonlinear \\
\hline ТP & $\begin{array}{c}0.6989 * * * \\
(7.7785)\end{array}$ & $\begin{array}{l}0.2462 * \\
(1.7867)\end{array}$ & $\begin{array}{l}0.6711^{*} \\
(1.8899)\end{array}$ & $\begin{array}{l}0.4405^{*} \\
(1.8649)\end{array}$ & $\begin{array}{l}0.3434^{*} \\
(1.8071)\end{array}$ & $\begin{array}{l}0.9524^{* *} \\
(2.2993)\end{array}$ & $\begin{array}{l}0.3014 * * \\
(2.4286)\end{array}$ & $\begin{array}{c}0.723^{*} \\
(1.9166)\end{array}$ \\
\hline LOAN & $\begin{array}{l}0.3552^{* *} \\
(1.9944)\end{array}$ & $\begin{array}{l}-0.3525^{* *} \\
(-2.1237)\end{array}$ & $\begin{array}{l}0.8923^{* *} \\
(1.7918)\end{array}$ & $\begin{array}{l}-0.7632 * \\
(-1.6518)\end{array}$ & $\begin{array}{c}1.095 \\
(1.4793)\end{array}$ & $\begin{array}{l}-2.862^{* *} \\
(-1.9971)\end{array}$ & $\begin{array}{c}-0.0323 \\
(-0.0449)\end{array}$ & $\begin{array}{l}1.551^{* *} \\
(2.1715)\end{array}$ \\
\hline STOCK & $\begin{array}{l}-0.184 \\
(-1.8394)\end{array}$ & $\begin{array}{l}0.1972 * \\
(1.8879)\end{array}$ & $\begin{array}{l}-0.3205^{*} \\
(-1.6964)\end{array}$ & $\begin{array}{l}0.3252 \text { * } \\
(1.7073)\end{array}$ & $\begin{array}{l}-1.133^{* * *} \\
(-3.1648)\end{array}$ & $\begin{array}{c}1.207^{*} \\
(1.8244)\end{array}$ & $\begin{array}{c}0.1149 \\
(0.1529)\end{array}$ & $\begin{array}{c}0.6069 \\
(0.6355)\end{array}$ \\
\hline INSURE & $\begin{array}{c}-0.0629 \\
(-0.9782)\end{array}$ & $\begin{array}{l}-0.0776 \\
(-0.796)\end{array}$ & $\begin{array}{l}-0.0776 \\
(-0.4759)\end{array}$ & $\begin{array}{c}-0.0134 \\
(-0.0698)\end{array}$ & $\begin{array}{l}-0.4207^{* *} \\
(-2.0492)\end{array}$ & $\begin{array}{c}-0.0922 \\
(-0.2519)\end{array}$ & $\begin{array}{c}0.6948 \\
(0.6122)\end{array}$ & $\begin{array}{c}-0.3434 \\
(-0.3246)\end{array}$ \\
\hline GOV & $\begin{array}{c}-0.025 \\
(-0.0716)\end{array}$ & $\begin{array}{c}-0.0566 \\
(-0.0784)\end{array}$ & $\begin{array}{c}3.064 * \\
(1.7321)\end{array}$ & $\begin{array}{c}-1.19 \\
(-0.365)\end{array}$ & $\begin{array}{c}-13.78 \\
(-1.5325)\end{array}$ & $\begin{array}{c}27.27 \\
(1.545)\end{array}$ & $\begin{array}{c}-0.4789 \\
(-0.2)\end{array}$ & $\begin{array}{c}0.2189 \\
(0.0563)\end{array}$ \\
\hline FDI & $\begin{array}{l}-0.0924 \\
(-0.6375)\end{array}$ & $\begin{array}{l}-0.634^{* *} \\
(-2.0146)\end{array}$ & $\begin{array}{c}0.5982 \\
(0.5433)\end{array}$ & $\begin{array}{c}-1.177 \\
(-0.9124)\end{array}$ & $\begin{array}{l}-1.793 * * * \\
(-3.1966)\end{array}$ & $\begin{array}{l}2.989^{* *} \\
(2.1675)\end{array}$ & $\begin{array}{c}-0.5564 \\
(-0.7527)\end{array}$ & $\begin{array}{c}0.2436 \\
(0.1974)\end{array}$ \\
\hline ESC & $\begin{array}{c}0.05 \\
(0.2269)\end{array}$ & $\begin{array}{l}-0.1516 \\
(-0.5181)\end{array}$ & $\begin{array}{c}3.032 \\
(0.9434)\end{array}$ & $\begin{array}{c}-4.29 * \\
(-1.6559)\end{array}$ & $\begin{array}{l}-2.332 * * * \\
(-3.0721)\end{array}$ & $\begin{array}{l}4.028^{* * * *} \\
(3.2484)\end{array}$ & $\begin{array}{l}-0.5276 \\
(-0.7376)\end{array}$ & $\begin{array}{c}0.8585 \\
(1.0738)\end{array}$ \\
\hline IS & $\begin{array}{l}-0.0139 * \\
(-1.847)\end{array}$ & $\begin{array}{c}0.0224 \\
(1.3088)\end{array}$ & $\begin{array}{l}-0.1121 * \\
(-1.7138)\end{array}$ & $\begin{array}{c}0.0895 \\
(1.4234)\end{array}$ & $\begin{array}{l}-0.0144 \\
(-0.7736)\end{array}$ & $\begin{array}{c}0.0224 \\
(0.6116)\end{array}$ & $\begin{array}{c}0.1308 \\
(0.7832)\end{array}$ & $\begin{array}{c}-0.228 \\
(-1.3793)\end{array}$ \\
\hline c & \multicolumn{2}{|c|}{4.989} & \multicolumn{2}{|c|}{3.9067} & \multicolumn{2}{|c|}{3.65} & \multicolumn{2}{|c|}{3.162} \\
\hline$\gamma$ & \multicolumn{2}{|c|}{1.82} & \multicolumn{2}{|c|}{0.8968} & \multicolumn{2}{|c|}{0.6236} & \multicolumn{2}{|c|}{0.3328} \\
\hline $\begin{array}{l}\text { Number of } \\
\text { observations }\end{array}$ & \multicolumn{2}{|c|}{420} & \multicolumn{2}{|c|}{154} & \multicolumn{2}{|c|}{112} & \multicolumn{2}{|c|}{154} \\
\hline
\end{tabular}

Note: t-statistics are shown in parentheses below the estimated coefficients. ${ }^{*}, * *$, and ${ }^{* * *}$ denote statistical significance at the $10 \%, 5 \%$, and $1 \%$ levels, respectively.

The impact of different financial sector support on energy efficiency is different. Table 7 indicates that the threshold EDL for the whole sample is 4.495, 4.394 for the east region, 4.31 for the central region, and 2.966 for the west region. The results show that the positional parameter of the whole sample is 4.495, which means that the value of its per capita GDP variable is 4.495, which indicates that the energy efficiency is affected by the different effects of financial support. When the per capita GDP value is lower than 4.495, the PSTR model tends towards the low regime, and the maximum value of bank support for energy efficiency promotion is 0.4956 . When the per capita GDP value is greater than 4.495, the PSTR model tends towards the high regime, and the effect of bank support on energy efficiency eventually weakens to 0.2602 through the smooth transfer function. This means 
that the increase in per capita GDP will decrease the impact of bank support on energy efficiency. When the PSTR model tends towards the low regime, the maximum value of the securities support for energy efficiency promotion is -0.019 . When the PSTR model tends towards the high regime, the impact of the securities support on energy efficiency increases to -0.0058 through the smooth transfer function. The increase in per capita GDP will increase the impact of securities support on energy efficiency. The impact of the insurance support on energy efficiency is not significant. There are similar conclusions in the east, central, and west regions.

Table 10. Interaction coefficient estimation of the PSTR model: FIN.

\begin{tabular}{|c|c|c|c|c|c|c|c|c|}
\hline \multirow[t]{2}{*}{ Variable } & \multicolumn{2}{|c|}{ Whole } & \multicolumn{2}{|c|}{ East } & \multicolumn{2}{|c|}{ Central } & \multicolumn{2}{|c|}{ West } \\
\hline & Linear & Nonlinear & Linear & Nonlinear & Linear & Nonlinear & Linear & Nonlinear \\
\hline $\mathrm{TP} \times \mathrm{LOAN}$ & $\begin{array}{c}0.6144^{* * *} \\
(8.7721)\end{array}$ & $\begin{array}{l}-0.1238 * \\
(-1.7288)\end{array}$ & $\begin{array}{c}0.7474^{* * *} \\
(5.83)\end{array}$ & $\begin{array}{c}-0.2358^{* *} \\
(-2.3323)\end{array}$ & $\begin{array}{c}1.301 * * * \\
(3.587)\end{array}$ & $\begin{array}{l}-1.21 * * * \\
(-3.975)\end{array}$ & $\begin{array}{c}0.4933^{* * *} \\
(7.23)\end{array}$ & $\begin{array}{c}-0.0186 \\
(-0.0922)\end{array}$ \\
\hline $\mathrm{TP} \times \mathrm{STOCK}$ & $\begin{array}{l}-0.2791 * \\
(-1.8022)\end{array}$ & $\begin{array}{l}0.2959 * \\
(1.833)\end{array}$ & $\begin{array}{l}-0.657^{* *} \\
(-1.9121)\end{array}$ & $\begin{array}{c}0.677^{*} \\
(1.9113)\end{array}$ & $\begin{array}{c}-0.8006 \\
(-2.754)\end{array}$ & $\begin{array}{l}1.353^{* * *} \\
(3.6099)\end{array}$ & $\begin{array}{c}-0.1145^{* * *} \\
(-3.7321)\end{array}$ & $\begin{array}{c}0.4725 \\
(1.0477)\end{array}$ \\
\hline TP $\times$ INSURE & $\begin{array}{l}0.039 * * \\
(2.5397)\end{array}$ & $\begin{array}{c}0.0075 \\
(0.3036)\end{array}$ & $\begin{array}{l}0.0477^{* *} \\
(2.1855)\end{array}$ & $\begin{array}{c}0.0158 \\
(0.5003)\end{array}$ & $\begin{array}{c}0.0502 \\
(0.4976)\end{array}$ & $\begin{array}{c}0.0249 \\
(0.2171)\end{array}$ & $\begin{array}{c}0.0458 \\
(1.0566)\end{array}$ & $\begin{array}{c}-0.0903 * * * \\
(-3.142)\end{array}$ \\
\hline GOV & $\begin{array}{l}-0.4026^{*} \\
(-1.6609)\end{array}$ & - & $\begin{array}{l}1.654^{*} \\
(1.934)\end{array}$ & - & $\begin{array}{c}0.6179 \\
(0.9393)\end{array}$ & - & $\begin{array}{c}-0.7115^{* * *} \\
(-4.6443)\end{array}$ & - \\
\hline FDI & $\begin{array}{l}-0.3057^{* *} \\
(-2.2813)\end{array}$ & - & $\begin{array}{l}-0.3722 * * \\
(-2.3497)\end{array}$ & - & $\begin{array}{c}0.1 \\
(0.3526)\end{array}$ & - & $\begin{array}{c}-0.3519 \\
(-1.5267)\end{array}$ & - \\
\hline ESC & $\begin{array}{c}0.2453 \\
(1.2586)\end{array}$ & - & $\begin{array}{c}0.4885 \\
(0.8321)\end{array}$ & - & $\begin{array}{c}0.0708 \\
(0.3969)\end{array}$ & - & $\begin{array}{c}0.1211 \\
(1.1339)\end{array}$ & - \\
\hline IS & $\begin{array}{l}-0.0156^{* *} \\
(-2.6652)\end{array}$ & - & $\begin{array}{l}-0.0494 * * \\
(-2.3452)\end{array}$ & - & $\begin{array}{l}-0.0068 \text { ** } \\
(-2.5013)\end{array}$ & - & $\begin{array}{l}-0.0071 \\
(-0.878)\end{array}$ & - \\
\hline c & \multicolumn{2}{|c|}{4.213} & \multicolumn{2}{|c|}{4.035} & \multicolumn{2}{|c|}{3.251} & \multicolumn{2}{|c|}{5.858} \\
\hline$\gamma$ & \multicolumn{2}{|c|}{1.354} & \multicolumn{2}{|c|}{1.973} & \multicolumn{2}{|c|}{0.5452} & \multicolumn{2}{|c|}{1.377} \\
\hline $\begin{array}{l}\text { Number of } \\
\text { observations }\end{array}$ & \multicolumn{2}{|c|}{420} & \multicolumn{2}{|c|}{154} & \multicolumn{2}{|c|}{112} & \multicolumn{2}{|c|}{154} \\
\hline
\end{tabular}

Note: t-statistics are shown in parentheses below the estimated coefficients. ${ }^{*}, * *$, and ${ }^{* * *}$ denote statistical significance at the $10 \%, 5 \%$, and $1 \%$ levels, respectively.

Table 9 indicates that the threshold FIN for the whole sample is 4.989, 3.9067 for the east region, 3.65 for the central region, and 3.162 for the west region. The results show that the positional parameter of the whole sample is 4.989 , which means that the threshold of FIN variable is 4.495 . When the FIN value is lower than 4.989 , the PSTR model tends towards the low regime, and the maximum value of bank support for energy efficiency promotion is 0.3552 When the per capita GDP value is greater than 4.989, the PSTR model tends towards the high regime, and the effect of bank support on energy efficiency eventually weakens to 0.0027 through the smooth transfer function. This means that the increase in the level of financial development will decrease the impact of bank support on energy efficiency. When the PSTR model tends towards the low regime, the maximum value of securities support for energy efficiency promotion is -0.184 . When the PSTR model tends towards the high regime, the impact of the securities support on energy efficiency increases to 0.0132 through the smooth transfer function. The increase in level of financial development will increase the impact of securities support on energy efficiency. The impact of the insurance support on energy efficiency is not significant. There are similar conclusions in the east, central, and west regions.

Financial support has different impacts on energy efficiency in different regions when the level of economic development is used as a transition variable. For the east region, when per capita GDP is below the threshold of 4.394, financial support has a positive impact on energy efficiency. When per capita GDP is above the threshold of 4.394, bank support for energy efficiency will be greatly reduced (from 1.056 to 0.052$)$, while securities support $(-0.07)$ and insurance support $(-0.009)$ on the contrary will have a negative impact on energy efficiency. For the central region, the higher the level of economic development, the more obvious the role of bank support (from 0.23 to 1.443) and securities support (from 0.0603 to 0.1755 ) in promoting energy efficiency. When the economic development level is at a low regime, insurance support $(-0.0937)$ has a negative impact on energy efficiency. When the economic development level is at a high regime the negative impact of insurance support (0.0035) on 
energy efficiency will be greatly diminished. For the west region, the higher the level of economic development, the more obvious the role of bank support (from 0.3462 to 0.8647 ) in promoting energy efficiency. When the economic development level is at a low regime, securities support $(-0.0157)$ has a negative impact on energy efficiency, and insurance support (0.0316) has a positive impact on energy efficiency. When the development level is at a high regime, the impact of securities support (from -0.0157 to 0.7168 ) on energy efficiency shifts from negative to positive, while the impact of insurance support (from 0.0316 to -0.1233 ) on energy efficiency shifts from positive to negative.

\subsection{PSTR Estimates of Financial Development}

Considering the level of financial development as a transition variable, for the east region, when FIN is below the threshold of 3.9067, bank support (0.8923) has a positive impact on energy efficiency, but securities support $(-0.3205)$ has a negative impact on energy efficiency. When FIN is above the threshold of 3.9067, bank support (from 0.8923 to 0.1291 ) for energy efficiency will be greatly reduced, while securities support (from -0.3205 to 0.0007 ) will have a positive impact on energy efficiency. For the central region, as the level of financial development increases, the impact of bank support (from 1.095 to -1.767 ) on energy efficiency shifts from positive to negative, while the impact of securities support (from -1.133 to 0.074 ) on energy efficiency shifts from negative to positive, and the negative impact of insurance support on energy efficiency will increase. For the west region, when the financial development level is at a low regime, the impact of financial support on energy efficiency has not passed significance testing. Further, when the financial development level is at a high regime, only bank support has a positive impact on energy efficiency.

Technological progress always has a positive impact on energy efficiency. It can be seen from Table 7 that the higher level of economic development, the more obvious the improvement regarding energy efficiency resulting from technological progress. However, the impact of technological progress on energy efficiency will vary from region to region When the economic development level is at a low regime, technological progress has the greatest impact on energy efficiency in the central region, at 0.7021 , with minimal impact on energy efficiency in the west region, only 0.3716 . When the economic development level is at a high regime, the impact of technological progress on energy efficiency in the east, central, and west regions reached $0.8383,1.0394$, and 0.8484 , respectively. From Table 9, similar conclusions can be drawn. When the financial development level is at a low regime, technological progress has the greatest impact on energy efficiency in the east region, at 0.6711 , with minimal impact on energy efficiency in the west region, only 0.3014 . When the financial development level is at a high regime, the impact of technological progress on energy efficiency in the east, central, and west regions reached 1.1167, 1.2958, and 1.0244, respectively. The difference in the impact of technological progress on energy efficiency between different regions has decreased.

Financial support has a non-linear effect on energy efficiency through technological progress. The empirical results of interactions between financial support and technological progress are shown in Tables 8 and 10. Most of the impact of the interaction between bank support and technological progress in different regions on energy efficiency has passed the significance test. Whether in the full sample or in the three sub-samples of east, central, and west, there are similar conclusions. When the economic and financial development level is at a low regime, bank support will have a positive impact on energy efficiency through technological progress. When the economic and financial development level is at a high regime, the positive impact of bank support on energy efficiency through technological progress will decline. For securities support, whether in the full sample or in the three sub-samples of east, central, and west, there are similar conclusions. When the economic and financial development level is at a low regime, securities support will have a negative impact on energy efficiency through technological progress. When the economic and financial development level is at high regime, the impact of securities support on energy efficiency through technological advancement will shift from negative to positive. The impact of the interaction between insurance support and the effect technological progress in different regions on energy efficiency has not passed 
the significance test. This shows that overall financial support, bank support, and securities support will have a non-linear impact on energy efficiency through technological progress.

\section{Conclusions}

In this paper, we use the DEA-Malmquist model to measure the energy efficiency for 30 provinces from China over the period of 2003 to 2016. The data were sub-divided into the east, central, and west sub-samples to study the nonlinear relationship between financial support and energy efficiency. We used the PSTR to conduct an empirical test. The main conclusions drawn from this analysis are as follows.

Technological progress is the main factor in improving energy efficiency. In order to cope with increasingly serious environmental pressure, attention should be paid to technological innovation and research and development. In short, technological progress is the main way to improve energy efficiency, reduce energy consumption, and achieve sustainable economic development.

In the financial sector, banks have the greatest impact on energy efficiency. When the economic and financial development is at a high regime, the positive impact of bank support on energy efficiency will be weakened. Banks have always been in the main position in China's financial system. When the market mechanism has not been established, the bank-led indirect financing model is conducive to ensuring enterprises improve energy efficiency. However, with the improvement of economic and financial levels and the continuous improvement of the market, the effect of banks on the improvement of the energy efficiency of enterprises has declined. This is mainly because the investment targets of the Chinese banking sector are guided by the government, and the state-owned industrial enterprises with lower energy efficiency are more likely to receive relevant financing services. Therefore, banks should consider the impact of corporate environmental protection factors when selecting investment targets.

When economic and financial development are at a high regime, securities support will have a positive impact on energy efficiency. This shows that when economic and financial development is at a low level, the imperfect development of the capital market will reduce energy efficiency, but with the development of the economic and financial environments, the securities market plays a positive role in improving energy efficiency. This shows that the capital market and direct financing are of great significance to the improvement of energy efficiency. Therefore, attention should be paid to the development of capital markets and the direct financing ability of enterprises.

The impact of insurance support on energy efficiency is not significant. This shows that China's insurance market has not yet formed a good relationship with enterprise development. At present, insurance is mainly for individuals and property. In the future, the scope of insurance services should be expanded, and insurance products be related to enterprise $R$ and $D$ to increase the willingness of enterprises to invest in $R$ and $D$.

Author Contributions: Conceptualization, S.C. and G.L.; methodology, G.L.; software, G.L.; validation, S.C., G.L., B.D., and P.F.; formal analysis, S.C. and G.L.; investigation, S.C.; resources, S.C.; data curation, S.C..; writing —original draft preparation, S.C. and G.L.; writing—review and editing, B.D. and P.F.; supervision, S.C.

Funding: This research received no external funding.

Conflicts of Interest: The authors declare no conflict of interest.

\section{References}

1. Li, C.; Song, Y. Government response to climate change in China: A study of provincial and municipal plans. J. Environ. Plan. Manag. 2016, 59, 1679-1710. [CrossRef]

2. Liu, Q.; Wang, Q. How China achieved its 11th Five-Year Plan emissions reduction target: A structural decomposition analysis of industrial $\mathrm{SO}_{2}$ and chemical oxygen demand. Sci. Total Environ. 2017, 574, 1104-1116. [CrossRef]

3. Hou, J.; Teo, T.S.; Zhou, F.; Lim, M.K.; Chen, H. Does industrial green transformation successfully facilitate a decrease in carbon intensity in China? An environmental regulation perspective. J. Clean Prod. 2018, 184, 1060-1071. [CrossRef] 
4. Li, C. Essays on Climate Change Mitigation, Building Energy Efficiency, and Urban Form. Ph.D Dissertation, The University of North Carolina, Chapel Hill, NC, USA, 2018.

5. Xu, C.; Wang, Y.; Li, L.; Wang, P. Spatiotemporal Trajectory of China's Provincial Energy Efficiency and Implications on the Route of Economic Transformation. Sustainability 2018, 10, 4582. [CrossRef]

6. Gökgöz, F.; Güvercin, M.T. Energy security and renewable energy efficiency in EU. Renew. Sustain. Energy Rev. 2018, 96, 226-239. [CrossRef]

7. Jo, H.; Kim, H.; Park, K. Corporate Environmental Responsibility and Firm Performance in the Financial Services Sector. J. Bus. Ethic. 2015, 131, 257-284. [CrossRef]

8. Ghisetti, C.; Rennings, K. Environmental innovations and profitability: How does it pay to be green? An empirical analysis on the German innovation survey. J. Clean. Prod. 2014, 75, 106-117. [CrossRef]

9. Tong, X.; Li, X.; Tong, L.; Jiang, X. Spatial Spillover and the Influencing Factors Relating to Provincial Carbon Emissions in China Based on the Spatial Panel Data Model. Sustainability 2018, 10, 4739. [CrossRef]

10. Li, Z.; Liao, G.; Wang, Z.; Huang, Z. Green loan and subsidy for promoting clean production innovation. J. Clean Prod. 2018, 187, 421-431. [CrossRef]

11. Li, Z.; Wang, Z.; Huang, Z. Modeling Business Cycle with Financial Shocks Basing on Kaldor-Kalecki Model. Quant. Financ. Econ. 2017, 1, 44-66. [CrossRef]

12. Qamruzzaman, M.; Jianguo, W. Investigation of the asymmetric relationship between financial innovation, banking sector development, and economic growth. Quant. Financ. Econ. 2018, 2, 952-980. [CrossRef]

13. Gerarden, T.D.; Newell, R.G.; Stavins, R.N. Assessing the energy-efficiency gap. J. Econ. Lit. 2017, 55, $1486-1525$. [CrossRef]

14. Costantini, V.; Crespi, F.; Marin, G.; Paglialunga, E. Eco-innovation, sustainable supply chains and environmental performance in European industries. J. Clean Prod. 2017, 155, 141-154. [CrossRef]

15. Benfratello, L.; Schiantarelli, F.; Sembenelli, A. Banks and Innovation: Microeconometric Evidence on Italian Firms. J. Financ. Econ. 2008, 90, 197-217. [CrossRef]

16. Kenney, M. How Venture Capital Became a Component of the US National System of Innovation. Ind. Corp. Chang. 2011, 20, 1677-1723. [CrossRef]

17. Brown, J.R.; Martinsson, G.; Petersen, B.C. Law, Stock Markets, and Innovation. J. Financ. 2013, 68, 1517-1549. [CrossRef]

18. Hsu, P.H.; Tian, X.; Xu, Y. Financial Development and Innovation: Cross-Country Evidence. J. Financ. Econ. 2014, 112, 116-135. [CrossRef]

19. King, R.G.; Levine, R. Finance and growth: Schumpeter might be right. Q. J. Econ. 1993, 108, 717-737. [CrossRef]

20. Amore, M.D.; Schneider, C.; Zaldokas, A. Credit Supply and Corporate Innovation. J. Financ. Econ. 2013, 109, 835-855. [CrossRef]

21. Kim, J.; Park, K. Financial development and deployment of renewable energy technologies. Energy Econ. 2016, 59, 238-250. [CrossRef]

22. Katircioğlu, S.T.; Taşpinar, N. Testing the moderating role of financial development in an environmental Kuznets curve: Empirical evidence from Turkey. Renew. Sustain. Energy Rev. 2017, 68, 572-586. [CrossRef]

23. Saidi, K.; Mbarek, M.B. The impact of income, trade, urbanization, and financial development on $\mathrm{CO}_{2}$ emissions in 19 emerging economies. Environ. Sci. Pollut. Res. 2017, 24, 12748-12757. [CrossRef] [PubMed]

24. Shahzad, S.J.H.; Kumar, R.R.; Zakaria, M.; Hurr, M. Carbon emission, energy consumption, trade openness and financial development in Pakistan: A revisit. Renew. Sustain. Energy Rev. 2017, 70, 185-192. [CrossRef]

25. Pata, U.K. Renewable energy consumption, urbanization, financial development, income and $\mathrm{CO}_{2}$ emissions in Turkey: Testing EKC hypothesis with structural breaks. J. Clean Prod. 2018, 187, 770-779. [CrossRef]

26. Huang, Y.; Kou, G.; Peng, Y. Nonlinear manifold learning for early warnings in financial markets. Eur. J. Oper. Res. 2017, 258, 692-702. [CrossRef]

27. Dahlhaus, T. Conventional monetary policy transmission during financial crises: An empirical analysis. J. Appl. Econ. 2017, 32, 401-421. [CrossRef]

28. Li, Z.; Hao, D.; Huang, Z.; Failler, P. Asymmetric Effects on Risks of Virtual Financial Assets (VFAs) in different regimes: A Case of Bitcoin. Quant. Financ. Econ. 2018, 2, 860-883. [CrossRef]

29. Shahbaz, M.; Van Hoang, T.H.; Mahalik, M.K.; Roubaud, D. Energy consumption, financial development and economic growth in India: New evidence from a nonlinear and asymmetric analysis. Energy Econ. 2017, 63, 199-212. [CrossRef] 
30. Fouquau, J.; Hurlin, C.; Rabaud, I. The Feldstein-Horioka puzzle: A panel smooth transition regression approach. Econ. Model. 2008, 25, 284-299. [CrossRef]

31. Wang, K.; Wei, Y.M.; Zhang, X. Energy and emissions efficiency patterns of Chinese regions: A multi-directional efficiency analysis. Appl. Energy 2013, 104, 105-116. [CrossRef]

32. Shahbaz, M.; Bhattacharya, M.; Mahalik, M.K. Financial development, industrialization, the role of institutions and government: A comparative analysis between India and China. Appl. Econ. 2018, 50, 1952-1977. [CrossRef]

33. Meng, Y.; Yang, Y.; Chung, H.; Lee, P.-H.; Shao, C. Enhancing Sustainability and Energy Efficiency in Smart Factories: A Review. Sustainability 2018, 10, 4779. [CrossRef]

34. Wen, J.; Yang, D.; Feng, G.F.; Dong, M.; Chang, C.P. Venture capital and innovation in China: The non-linear evidence. Struct. Chang. Econ. Dyn. 2018, 46, 148-162. [CrossRef]

35. Yao, X.; Zhou, H.; Zhang, A.; Li, A. Regional energy efficiency, carbon emission performance and technology gaps in China: A meta-frontier non-radial directional distance function analysis. Energy Policy 2015, 84, 142-154. [CrossRef]

36. Ouyang, X.; Wei, X.; Sun, C.; Du, G. Impact of factor price distortions on energy efficiency: Evidence from provincial-level panel data in China. Energy Policy 2018, 118, 573-583. [CrossRef]

37. Chen, Y.; Cook, W.D.; Du, J.; Hu, H.; Zhu, J. Bounded and discrete data and Likert scales in data envelopment analysis: Application to regional energy efficiency in China. Ann. Oper. Res. 2017, 255, 347-366. [CrossRef]

38. Li, M.J.; Tao, W.Q. Review of methodologies and polices for evaluation of energy efficiency in high energy-consuming industry. Appl. Energy 2017, 187, 203-215. [CrossRef]

39. Zhang, M.; Liu, X.; Wang, W.; Zhou, M. Decomposition analysis of $\mathrm{CO}_{2}$ emissions from electricity generation in China. Energy Policy 2013, 52, 159-165. [CrossRef]

40. Filippini, M.; Zhang, L. Estimation of the energy efficiency in Chinese provinces. Energy Effic. 2016, 9, 1315-1328. [CrossRef]

41. Al-Refaie, A.; Hammad, M.; Li, M.H. DEA window analysis and Malmquist index to assess energy efficiency and productivity in Jordanian industrial sector. Energy Effic. 2016, 9, 1299-1313. [CrossRef]

42. Li, Z.; Chen, S.; Chen, S. Statistical Measure of Validity of Financial Resources Allocation. EURASIA J. Math. Sci. Tech. Ed. 2017, 13, 7731-7741. [CrossRef]

43. Cheng, G. Data Envelopment Analysis: Methods and MaxDEA Software; Intellectual Property Pub: Beijing, China, 2014.

44. Levin, A.; Lin, C.F.; Chu, C. Unit root tests in panel data: Asymptotic and finite-sample properties. J. Econ. 2002, 108, 1-24. [CrossRef]

45. Maddala, G.S.; Wu, S.A. Comparative study of unit root tests with panel data and a new simple test. Oxf. Bull. Econ. Stat. 1999, 108, 1-24. [CrossRef]

(C) 2019 by the authors. Licensee MDPI, Basel, Switzerland. This article is an open access article distributed under the terms and conditions of the Creative Commons Attribution (CC BY) license (http://creativecommons.org/licenses/by/4.0/). 